\title{
Troglitazone inhibits the migration and invasion of PC-3 human prostate cancer cells by upregulating E-cadherin and glutathione peroxidase 3
}

\author{
SEO-NA CHANG, JI MIN LEE, HANSEUL OH, UKJIN KIM, BOKYEONG RYU and JAE-HAK PARK \\ Department of Laboratory Animal Medicine, College of Veterinary Medicine, \\ Seoul National University, Seoul 151-742, Republic of Korea
}

Received September 24, 2016; Accepted April 28, 2017

DOI: $10.3892 / \mathrm{ol} .2018 .9278$

\begin{abstract}
Troglitazone (TGZ) is a synthetic peroxisome proliferator-activated receptor $\gamma(\operatorname{PPAR} \gamma)$ ligand that exhibits potential antitumor effects on a number of cancer subtypes, including prostate cancer. However, little is known about the effect of TGZ on metastasis in prostate cancer. The aim of the present study was to determine the inhibitory effect and mechanism underlying TGZ on cell growth, migration and invasion using the prostate cancer PC-3 cell line. Cellular migration and invasion were evaluated by performing a wound healing assay and Matrigel assay, respectively. The expression levels of mRNA and protein were determined by reverse transcription-quantitative polymerase chain reaction and western blotting. The results demonstrated that TGZ dose-dependently inhibited cell migration and invasion of PC-3 cells. The present study also revealed that TGZ increased the mRNA and protein levels of E-cadherin and glutathione peroxidase 3 (GPx3) in human prostate cancer PC-3 cells. In addition, GW9662, a PPAR $\gamma$ antagonist, attenuated the increased mRNA and protein levels of E-cadherin and GPx3, suggesting that the PPAR $\gamma$-dependent signaling pathway was involved. Taken together, these results suggested that the anti-migration and anti-invasion effect of TGZ on PC-3 prostate cancer cells is, at least in part, mediated via upregulation of E-cadherin and GPx3. The present study also concluded that PPAR $\gamma$ may be used as a potential remedial target for the prevention and treatment of prostate cancer cell invasion and metastasis.
\end{abstract}

Correspondence to: Professor Jae-Hak Park, Department of Laboratory Animal Medicine, College of Veterinary Medicine, Seoul National University, 1 Kwanakro, Kwanak-gu, Seoul 151-742, Republic of Korea

E-mail: pjhak@snu.ac.kr

Key words: prostate cancer, thiazolidinediones, troglitazone, proliferator-activated receptor $\gamma$, E-cadherin, glutathione peroxidase 3, cell invasion

\section{Introduction}

Prostate cancer is the most common non-cutaneous malignancy in males. It is also the second leading cause of cancer-associated mortality in the western world amongst males (1). Androgen-deprivation therapy, a standard-of-care medicine for prostate cancer, is able to proficiently control the development of androgen-dependent tumors (2). Numerous patients with localized disease have improved long-term survival and elevated cure rates with standard therapies; however, the cancer eventually becomes resistant to hormone deprivation and progresses to castration-resistant prostate cancer $(2,3)$. The patients with locally advanced and metastatic disease have poor prognoses, leading to high morbidity and mortality rates $(2,3)$. Therefore, understanding the mechanisms underlying cancer invasion and subsequent metastasis are urgently required to develop therapies for combating metastatic prostate cancer.

Thiazolidinediones (TZDs), including troglitazone and ciglitazone, are synthetic ligands of peroxisome proliferator-activated receptor $\gamma(\operatorname{PPAR} \gamma)(4)$. They exhibit potential antitumor effects on numerous types of cancers (4-10), including prostate cancer (11-13). A previous study performed on prostate cancer cell lines has demonstrated that troglitazone (TGZ) decreases cellular proliferation, which is associated with increased expression levels of glutathione peroxidase 3 (GPx3) (11). TGZ has been investigated in clinical trials against breast, colorectal and prostate cancer(14-16). Treatment with TGZ in patients with advanced prostate cancer has been associated with long periods of stable disease characterized by the absence of new symptoms without new metastases (14), suggesting that TGZ may have clinical value in suppressing cancer metastasis. However, the role of TGZ in metastasis and the precise molecular mechanisms underlying its action have not been fully elucidated.

During cancer progression, epithelial-mesenchymal transition (EMT) is the main mechanism underlying the invasiveness and metastasis of cancer cells. EMT is a process that converts immotile epithelial cells to motile mesenchymal cells (17-19). Downregulation of epithelial marker E-cadherin expression is the hallmark of the EMT process. E-cadherin is a tumor suppressor that serves crucial roles in cell-cell adhesion (19). 
Loss of E-cadherin expression or function is associated with cancer cell invasion and metastasis (20).

The present study aimed to investigate the anti-invasive and anti-metastatic activities of TGZ and hypothesized that TGZ may act on various stages of the metastatic procedure to prevent cancer cells from metastasizing. The present study therefore determined the effect of TGZ on the reduction of cell invasive activity and also examined the effect of TGZ on the expression levels of E-cadherin and GPx3 in PC-3 human prostate cancer cells.

\section{Materials and methods}

Prostate cancer cell line. The human prostate cancer PC-3 cell line was acquired from the American Type Culture Collection (Manassas, VA, USA). These cells were cultured in RPMI medium (Gibco; Thermo Fisher Scientific, Inc. Waltham, MA, USA) supplemented with $10 \%$ fetal bovine serum (FBS; Gibco; Thermo Fisher Scientific, Inc.) and 1\% penicillin/streptomycin (Gibco; Thermo Fisher Scientific, Inc.) at $37^{\circ} \mathrm{C}$ in $95 \%$ air and $5 \% \mathrm{CO}_{2}$. TGZ (Sigma-Aldrich; Merck KGAa, Darmstadt, Germany) and GW9662 (Cayman Chemical Company, Ann Arbor, MI, USA) were dissolved in $100 \%$ ethanol (Merck $\mathrm{KGaA}$ ) to obtain a concentration of $16 \mathrm{mM}$. The final ethanol concentration in the solution was $0.25 \%$. Ethanol alone at the same final concentration of $0.25 \%$ was used as the control.

Cellular viability assay. The viability of PC-3 cells was analyzed using an MTT (Sigma-Aldrich; Merck KGaA) assay based on the ability of live cells to convert tetrazolium salt into purple formazan. Briefly, PC-3 cells were seeded into 96-well cell culture plates at a density of $8 \times 10^{3}$ cells/well in $200 \mu \mathrm{l}$ media. Following $24 \mathrm{~h}$ incubation at $37^{\circ} \mathrm{C}$, the medium was replaced with $1 \%$ FBS-RPMI medium at $37^{\circ} \mathrm{C}$ for $24 \mathrm{~h}$. Cells were treated with TGZ at concentrations of 1,10 and $40 \mu \mathrm{M}$ or vehicle (ethanol) control and cultured at $37^{\circ} \mathrm{C}$ for $48 \mathrm{~h}$. The medium was then replaced with $100 \mu \mathrm{l}$ of MTT (diluted to $1 \mathrm{mg} / \mathrm{ml}$ in FBS-free medium, from a stock solution of $10 \mathrm{mg} / \mathrm{ml}$ ) and incubated at $37^{\circ} \mathrm{C}$ for $3 \mathrm{~h}$. The supernatant was removed and $100 \mu \mathrm{l}$ of DMSO was supplemented to each well to dissolve the formazan crystals. Plates were agitated at room temperature for $5 \mathrm{~min}$. The absorbance was read at $540 \mathrm{~nm}$ on an Epoch BioTek microplate reader (BioTek Instruments, Inc., Winooski, VT, USA). All treatments were performed in triplicate.

Cellular migration assay. PC-3 cell motility was analyzed using an in vitro wound-healing assay. PC-3 cells were seeded into six-well cell culture plates at a density of $8 \times 10^{4}$ cells/well and grown until confluent at $37^{\circ} \mathrm{C}$. Monolayers of confluent PC-3 cells were then wounded using a pipette tip. Cell repair was monitored using an inverted microscope (Olympus IX70, Tokyo, Japan) following $24 \mathrm{~h}$ exposure at $37^{\circ} \mathrm{C}$ to $\mathrm{TGZ}$ at concentrations of 1,10 and $40 \mu \mathrm{M}$ or the vehicle (ethanol) control. The widths of the wounded areas were measured by Image J software (version 1.48; National Institutes of Health, Bethesda, MD, USA), and the relative wound closure ratios of the distance to that at $0 \mathrm{~h}$ were calculated at $6,9,12$ and $24 \mathrm{~h}$. All treatments were performed in triplicate.
Cellular invasion assay. PC-3 cellular invasion was determined using a Transwell insert. Briefly, $8 \mu \mathrm{m}$ Transwell inserts (SPL Life Sciences, Pocheon, Korea) were coated with Matrigel (Gibco; Thermo Fisher Scientific, Inc.) and incubated at $37^{\circ} \mathrm{C}$ for $2 \mathrm{~h}$ to become gelatinous. Cells were grown to subconfluence, detached by trypsinization, washed twice with PBS and resuspended in serum free RPMI medium. Subsequently, the cells added to the Transwell insert $\left(2 \times 10^{4}\right.$ cells/insert $)$ at a final concentration of $1 \times 10^{5}$ cells/ml together with TGZ at concentrations of 1,10 and $40 \mu \mathrm{M}$ or the vehicle (ethanol) control. Cell-free RPMI medium was added to the lower chamber. Assays were incubated at $37^{\circ} \mathrm{C}$ for $30 \mathrm{~h}$ until cells had migrated to the bottom of the membrane. Non-invasive cells in the upper surface of the membrane were removed with a cotton swab. The remaining cells on the membrane were fixed in methanol for $10 \mathrm{~min}$ at room temperature, stained with hematoxylin for 10 min at room temperature and washed with PBS. Invaded cells were counted in four fields per insert with a light microscope at x100 magnification. Cells were assessed for their relative invasion ability as percentages of the vehicle (ethanol) controls. All treatments were performed in triplicate.

Reverse transcription-quantitative polymerase chain reaction (RT-qPCR). Total RNA was extracted from PC-3 cells using a Hybrid-R RNA extraction kit (GeneAll Biotechnology, Seoul, South Korea), and then cDNA was synthesized using a M-MLV cDNA Synthesis kit (Enzynomics, Daejeon, South Korea) according to the manufacturer's protocol. RT-qPCR was performed using TOPreal ${ }^{\mathrm{TM}}$ qPCR 2X PreMIX (SYBR Green with high ROX; Enzynomics) on a CFX Connect Real-Time PCR Detection system (Bio-Rad Laboratories, Inc., Hercules, CA, USA). The reaction conditions were as follows: Pre-incubation at $94^{\circ} \mathrm{C}$ for $10 \mathrm{~min}$, followed by 40 cycles $\left(94^{\circ} \mathrm{C}\right.$ for $10 \mathrm{sec}, 58^{\circ} \mathrm{C}$ for $20 \mathrm{sec}, 72^{\circ} \mathrm{C}$ for $30 \mathrm{sec}$ ) ending with a melting curve program with temperature rising from 60 to $95^{\circ} \mathrm{C}$. The specificity of the reactions was verified by melting curve analysis. The primers used were: Human GPx3 sense, 5'-ACATGCCTACAGGTATGCGT-3 and antisense, 5'-GAG CAGAACAATTGGACCTA-3'; human E-cadherin sense, 5'-TTGCTACTGGAACAGGGACACT-3' and antisense 5'-GGAGATGTATTGGGAGGAAGGTC-3'; and human $\beta$-actin sense, 5'-CATGTACGTTGCTATCCAGGC-3' and antisense, 5'-CTCCTTAATGTCACGCACGAT-3'. The ratio of target gene fold-change was normalized to human $\beta$-actin expression level using the comparative $2^{-\Delta \Delta \mathrm{Cq}}$ method (21). All treatments were performed in triplicate.

Western blot analysis. Cell lysates were subjected to SDS-PAGE (on 10\% acrylamide gel), transferred to nitrocellulose membranes and probed with mouse monoclonal anti-E-cadherin primary antibody (sc-8426, Santa Cruz Biotechnology, Inc., Dallas, TX, USA; 1:1,000 dilution), mouse monoclonal anti-GPx3 primary antibody (ab27325, Abcam, Cambridge, MA, USA; 1:500 dilution) and goat polyclonal anti-actin primary antibody (sc-1616, Santa Cruz Biotechnology,Inc.; 1:1,000 dilution). Blots were incubated with horseradish peroxidase-conjugated anti-mouse Ig secondary antibodies (61-0120, Zymed; Thermo Fisher Scientific, Inc.; 1:2,000 dilution) and anti-goat Ig (81-1620, Zymed; 1:2,000 dilution). Then, the antibody reactive bands were developed 
using a chemiluminescent substrate (DoGEN, Seoul, South Korea). Blots were quantified with ImageJ software (version 1.48; National Institutes of Health), and the relative ratio was calculated.

Statistical analysis. All data are presented as the mean \pm standard error. Statistical significance was further analyzed by Student's t-test using Excel 2010 (Microsoft Corporation, Redmond, WA, USA). $\mathrm{P}<0.05$ was considered to indicate a statistically significant difference.

\section{Results}

Treatment with TGZ decreased cellular viability of PC-3 cells. To examine the effect of TGZ on the cellular viability of PC-3 cells, the present study treated these cells with 1,10 or $40 \mu \mathrm{M}$ TGZ for 0,24 or $48 \mathrm{~h}$, and determined the rate of cell survival using an MTT assay. Results are presented in Fig. 1. TGZ treatment decreased cellular viability in a dose-dependent manner. Compared with the control cells, cells treated with 10 and $40 \mu \mathrm{M}$ TGZ for $24 \mathrm{~h}$ demonstrated decreases in cell growth rates by 20.49 and $34.69 \%$, respectively.

TGZ inhibits cell migration and invasion of PC-3 cells. The present study evaluated cell migration and invasion of PC-3 cells treated with TGZ by in vitro wound healing and Matrigel assays. The results are presented in Figs. 2 and 3, respectively. Following incubation with various concentrations of TGZ for $24 \mathrm{~h}$, the migration of PC-3 cells to the denuded area was inhibited in a dose-dependent manner (Fig. 2), indicating that TGZ significantly suppressed the motility of PC- 3 cells.

Results of the Matrigel assay revealed that TGZ inhibited the invasion of PC-3 cells through the Matrigel-coated filter pores in a dose-dependent manner (Fig. 3). Treatment with 1,10 and $40 \mu \mathrm{M}$ TGZ inhibited 54.27, 65.63, and $73.70 \%$ of cell invasion, respectively. These results demonstrated that TGZ significantly inhibited the invasion of PC-3 cells. Taken together, these results revealed that TGZ suppressed cellular migration and invasion of PC-3 cells.

TGZ increases the mRNA levels of E-cadherin and GPX3 in $P C-3$ human prostate cancer cells. To investigate whether TGZ could enhance the transcriptional levels of E-cadherin and GPx3 genes in PC-3 cells, RT-qPCR was performed. The results are presented in Fig. 4. TGZ treatments of 1 and $10 \mu \mathrm{M}$ significantly increased the mRNA expression levels of E-cadherin in a dose-dependent manner (Fig. 4A). A TGZ treatment of $10 \mu \mathrm{M}$ also significantly increased the mRNA expression levels of GPx3 (Fig. 4B).

Although TGZ was able to affect the transcriptional expression levels of E-cadherin and GPx3, the mechanisms underlying these effects remain unclear. To prove whether these results were dependent on the activation of PPAR $\gamma$, GW9662 (a PPAR $\gamma$ antagonist) was used to inhibit the function of PPAR $\gamma$ in PC-3 cells. TGZ-induced upregulation of E-cadherin and GPx3 mRNAs in PC-3 cells were decreased following treatment with GW9662 (Fig. 4). These results demonstrated that TGZ increased the transcriptional expression levels of E-cadherin and GPx3 in PC-3 cells in a PPAR $\gamma$-dependent manner.

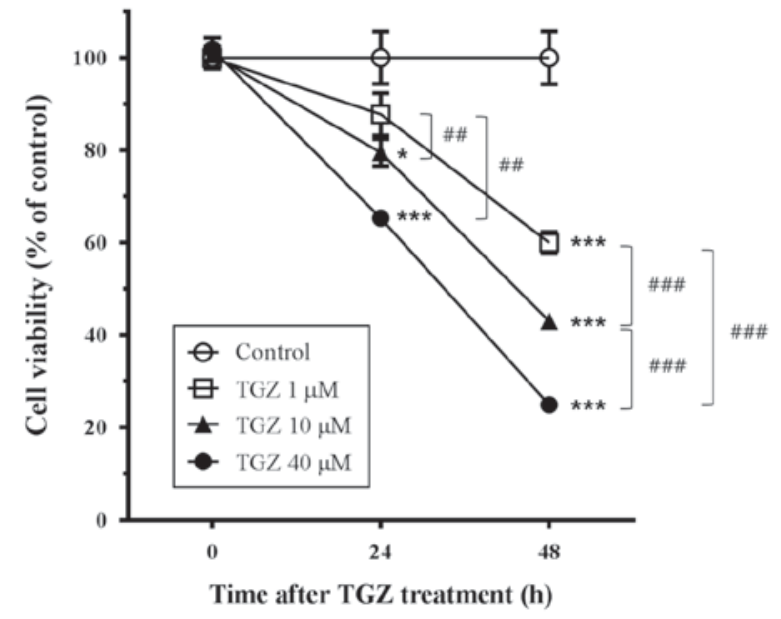

Figure 1. Effect of TGZ on the proliferation of PC-3 cells. TGZ inhibited the proliferation of PC-3 cells. The absorbance values of PC-3 cells treated with 1,10 and $40 \mu \mathrm{M}$ TGZ were read at $540 \mathrm{~nm}$ using a plate reader. The cell viability of cells was determined based on the proliferation of PC-3 cells compared with the proliferation of the vehicle control group. ${ }^{*} \mathrm{P}<0.05$ and ${ }^{* * *} \mathrm{P}<0.001$ vs. the vehicle (ethanol) control. ${ }^{\# \#} \mathrm{P}<0.01$ and ${ }^{\# \# \#} \mathrm{P}<0.001$, comparisons exhibited on graph. Results are presented as the mean \pm standard error of the mean. TGZ, troglitazone.

$T G Z$ increases the protein levels of E-cadherin and GPx3 in $P C-3$ human prostate cancer cells. The protein expression levels of E-cadherin and GPx 3 in PC-3 cells were determined by western blot analysis following $48 \mathrm{~h}$ treatment with 0,1 or $10 \mu \mathrm{M}$ TGZ. Results are presented in Fig. 5. TGZ at 1 and $10 \mu \mathrm{M}$ significantly increased the protein expression levels of E-cadherin in a dose-dependent manner (Fig. 5A and B). TGZ at $10 \mu \mathrm{M}$ also significantly increased the protein expression levels of GPx3 (Fig. 5A and C). TGZ-induced upregulation of E-cadherin and GPx3 protein expression levels in PC-3 cells were decreased following the addition of GW9662 (Fig. 5). Thus, TGZ upregulated E-cadherin and GPx3 protein expression levels in a PPAR $\gamma$-dependent manner, which was consistent with its upregulating effect on E-cadherin and GPx3 mRNA expression levels.

\section{Discussion}

TZDs are a novel class of antidiabetics and are specific ligands for PPAR $\gamma$ (22). PPAR $\gamma$ is expressed at various levels depending on the type of tissue and carcinoma (23). PPAR $\gamma$ has been investigated as a therapeutic target for cancer treatment. Certain previous studies have reported that PPAR $\gamma$ is able to induce anti-proliferative, anti-angiogenic and pro-differentiation signaling pathways in specific tissue types, thus serving a role in the pathogenesis and progression of various types of cancer, including prostate cancer $(24,25)$. Using TZDs as PPAR $\gamma$ ligands, previous studies have investigated the effect of PPAR $\gamma$ on the metastatic potential and investigated its underlying mechanisms (26-34). TZDs have been demonstrated to be able to suppress cellular migration, invasion and metastasis of cancer in the colon, liver, breast, lung, bladder and prostate gland (26-34). For example, in colon cancer, TZD inhibited the development and metastasis of HT-29 human colon cancer cells via its differentiation-promoting effects both in vivo and in vitro by involving the modulation of the $\mathrm{E}$-cadherin/ $\beta$-catenin 
A Control

TGZ $1 \mu \mathrm{M}$

TGZ $10 \mu \mathrm{M}$

TGZ $40 \mu \mathrm{M}$
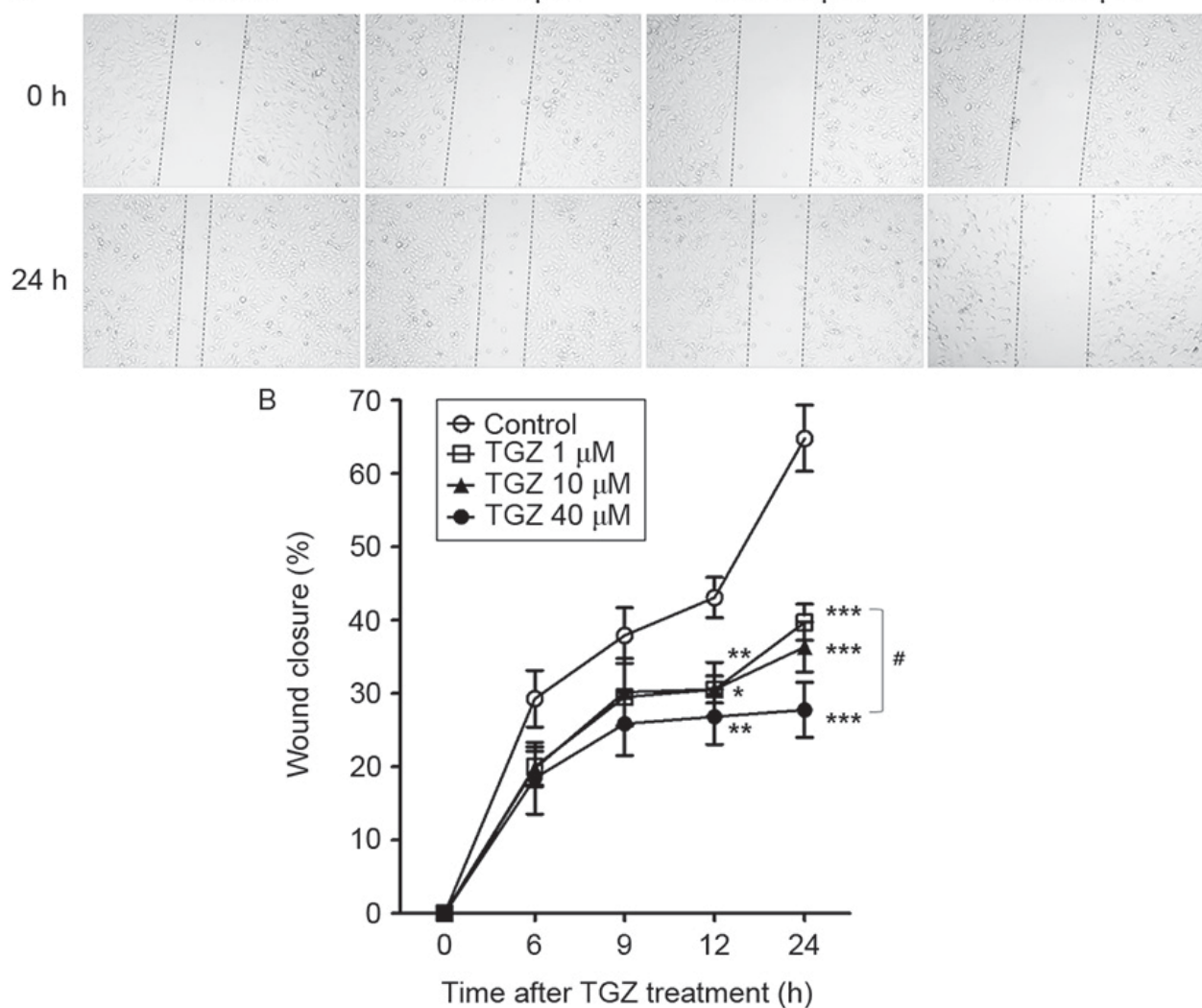

Figure 2. Effect of TGZ on the migration of PC-3 cells. TGZ suppressed the migration of PC-3 human prostate cancer cells. (A) Cells that migrated to the wounded region were imaged (magnification, $\mathrm{x} 40$ ). (B) Migration ability of PC-3 cells treated with 1,10 and $40 \mu \mathrm{M}$ TGZ was determined by wound healing assay. ${ }^{*} \mathrm{P}<0.05,{ }^{* *} \mathrm{P}<0.01$ and ${ }^{* * * *} \mathrm{P}<0.001$ compared with the vehicle control at each time point. ${ }^{*} \mathrm{P}<0.05$, comparison exhibited on graph. Results are presented as the mean \pm standard error of the mean. TGZ, troglitazone.
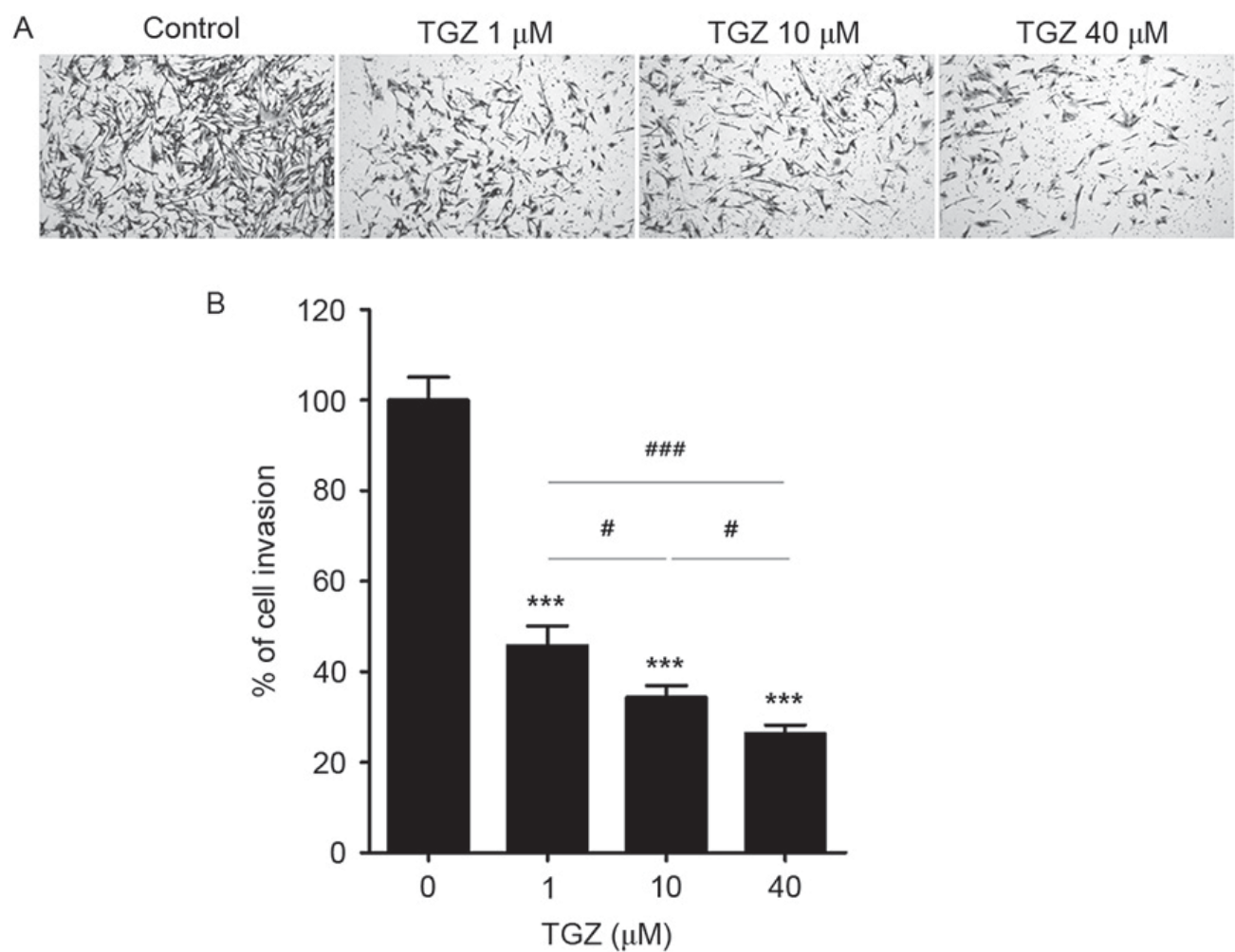

Figure 3. Effect of TGZ on the invasion of PC-3 cells. TGZ suppressed the invasion of PC-3 human prostate cancer cells. (A) Invaded cells were imaged (magnification, x100). (B) Invasion capacity was examined using a Transwell insert coated with Matrigel. ${ }^{* * * *} \mathrm{P}<0.001$ vs. the vehicle control. ${ }^{* \prime} \mathrm{P}<0.05$ and ${ }_{\# \# \# !} \mathrm{P}<0.001$, comparisons exhibited on graph. Results are presented as the mean \pm standard error of the mean. TGZ, troglitazone. 
A

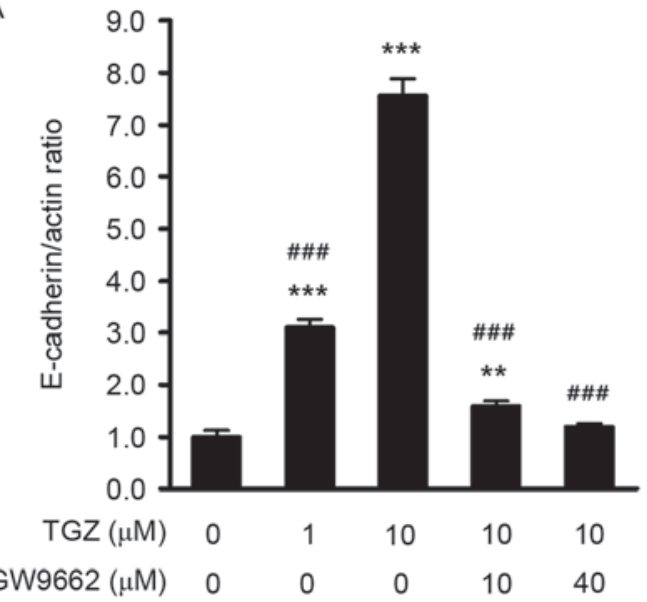

B

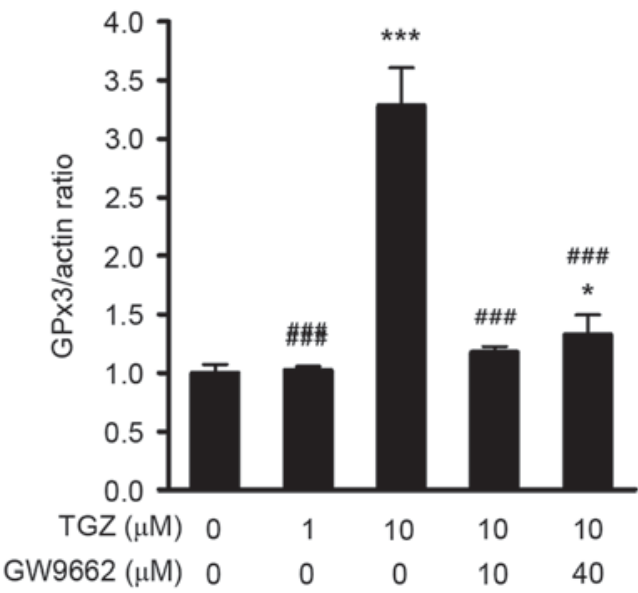

Figure 4. Effect of TGZ on mRNA expression levels of E-cadherin and GPx3 in PC-3 cells. TGZ upregulated the mRNA expression levels of E-cadherin and GPx3 in PC-3 cells. PC-3 cells were treated with various concentrations of TGZ $(0,1$ or $10 \mu \mathrm{M})$ for $24 \mathrm{~h}$ prior to harvesting. (A) Total RNA was extracted and the expression level of E-cadherin was evaluated by RT-qPCR. TGZ at 1 and $10 \mu \mathrm{M}$ increased the mRNA expression levels of E-cadherin in a dose-dependent manner. (B) GPx3 expression level was evaluated by RT-qPCR. TGZ at $10 \mu \mathrm{M}$ increased the mRNA expression level of GPx $3 .{ }^{*} \mathrm{P}<0.05,{ }^{* * *} \mathrm{P}<0.01$ and ${ }^{* * * *} \mathrm{P}<0.001$ vs. the vehicle control. ${ }^{\# \# \#} \mathrm{P}<0.001$ vs. the $10 \mu \mathrm{M}$ TGZ treatment group. Results are presented as the mean \pm standard error of the mean. TMZ, troglitazone; RT-qPCR, reverse transcription-quantitative polymerase chain reaction.
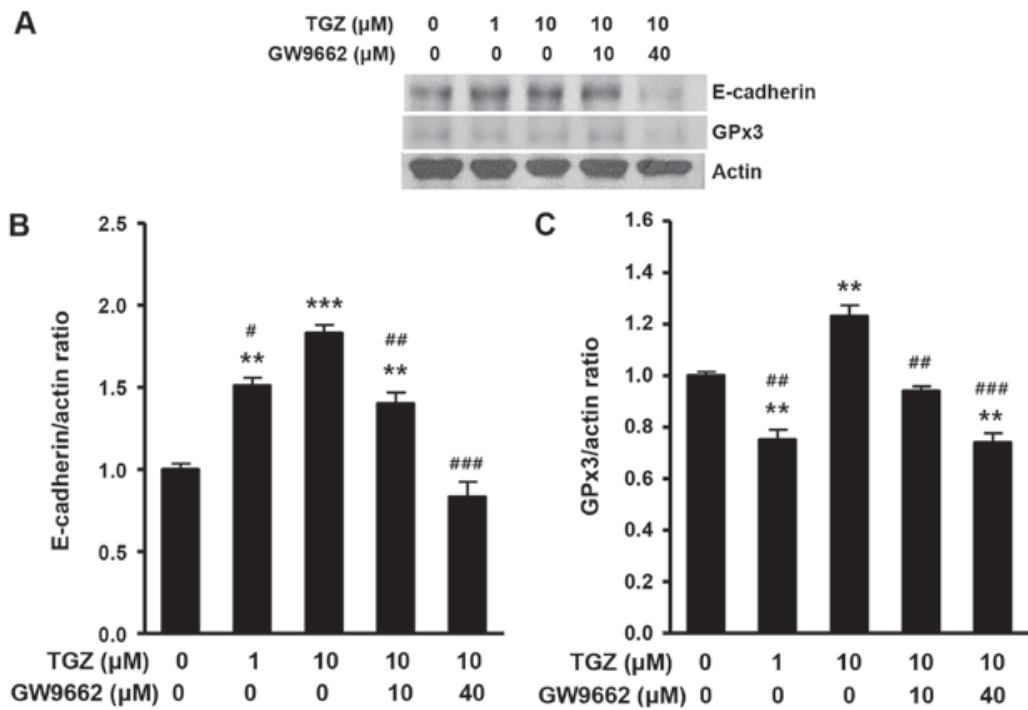

Figure 5. Effect of TGZ on protein expression levels of E-cadherin and GPx3 in PC-3 cells. TGZ increased the protein expression levels of E-cadherin and GPx3 in PC-3 cells. (A) Western blot analysis of the PC3 cell line. Protein expression levels of (B) E-cadherin and (C) GPx3 were quantified using actin as the normalization control. ${ }^{* *} \mathrm{P}<0.01$ and ${ }^{* * * *} \mathrm{P}<0.001$ vs. the vehicle control. ${ }^{\#} \mathrm{P}<0.05,{ }^{\# \#} \mathrm{P}<0.01$ and ${ }^{\# \# \#} \mathrm{P}<0.001$ vs. the $10 \mu \mathrm{M}$ TGZ treatment group. Results are presented as the mean \pm standard error of the mean. TMZ, troglitazone.

system (26). In hepatocellular carcinoma, the suppression of cellular invasion and migration mediated by PPAR $\gamma$ has been revealed to be mediated via downregulation of matrix metalloproteinases, by and increased expression levels of TIMP metallopeptidase inhibitor 3 and E-cadherin $(28,29)$.

However, the mechanisms underlying the inhibitory action of TZDs on cell invasion in prostate cancer remain unclear. To better comprehend the molecular mechanisms involved in TGZ-induced inhibition of cell invasion, the present study analyzed the effect of TGZ on the expression levels of E-cadherin and GPx3.E-cadherin and GPx3 may be involved in cancer cell invasion. The present study demonstrated that TGZ reduced cell migration and invasion of PC-3 cells. Consistently, TGZ positively regulated the mRNA and protein expression levels of E-cadherin and GPx3 in a PPAR $\gamma$-dependent manner. The results from the present study may provide preliminary evidence for further studies investigating the mechanisms underlying the suppression of metastasis by TZDs.

A number of human solid tumors are carcinomas originating from various epithelial cell types $(18,19)$. Tumor cells change from a highly differentiated epithelial morphology to a migratory and invasive phenotype during the conversion from a benign tumor to a malignant invasive tumor (18). This process of EMT can induce the loss of cell-cell contacts and an increase in cell motility $(18,35)$. It also induces the dissemination of single tumor cells from primary epithelial tumors to distant organs (19). These alterations are necessary for invasion. Throughout the EMT process, numerous genes involved 
in cellular adhesion, migration and invasion and mesenchymal differentiation are transcriptionally regulated (19). Amongst these genes, loss of adhesive function of E-cadherin in epithelial cells has been suggested to be a hallmark of EMT and metastatic carcinoma $(17,19,20,35)$.

E-cadherin formation is preserved in the majority of differentiated tumors, including carcinomas of the skin, head and neck, breast, lung, liver, colon and prostate (17-20). However, E-cadherin expression levels demonstrated an inverse correlation with cancer grade or patient survival (17). In a number of human and mouse types of cancer, carcinoma progression and poor prognosis have been revealed to be associated with partial loss of E-cadherin expression (19). Increasing E-cadherin function in cancer cells and mouse cancer models suppresses the ability to invade and metastasize (19). Conversely, disrupted expression of E-cadherin in noninvasive tumor cells induces invasive and metastatic activities $(18,19)$. In the present study, an increase in E-cadherin expression level induced increased cell-cell interactions and decreased motility of PC-3 cells following TGZ treatment. Therefore, changing the functional protein expression levels of E-cadherin may be an alternative approach for cancer therapy.

GPx3 belongs to the family of glutathione peroxidases (36). It is well known that glutathione peroxidases are among the most important reactive oxygen species scavengers that protect cells from oxidative damage (36). Downregulation of GPx3 by hypermethylation has been revealed in numerous types of cancer $(37-45)$, including prostate cancer $(11,46,47)$. In prostate cancer, a negative correlation between GPx3 expression levels and poor clinical outcomes has been demonstrated $(47,48)$. Forced expression of GPx3 in prostate cancer cell lines is able to suppress colony formation and cellular proliferation $(11,47,49)$. Xenografts with higher GPx3 expression levels have resulted in reduced tumor volume, metastasis and animal mortality (47). Our previous study revealed that GPx3 is downregulated in prostates of TRAMP mice and that disruption of GPx3 expression in TRAMP mice increased prostate cancer development and metastasis (50). It has been demonstrated that silencing GPx3 expression promoted cancer metastasis in human thyroid and gastric cancer cells $(37,38)$. In the present study, it was notable that GPx3 expression level was upregulated following treatment with TGZ in human prostate cancer cells. This induction was closely associated with the anti-invasion effect of TGZ. All these results suggested that GPx3 acted as a negative regulator of prostate tumor development and metastasis, producing further evidence for its role as a tumor suppressor.

In conclusion, the present study revealed that TGZ effectively abrogated the migration and invasion of PC-3 cells in vitro by increasing the expression levels of E-cadherin and GPx3. Upregulated expression levels of E-cadherin and GPx3 is a possible mechanism underlying the anti-migration and anti-invasion effects of TGZ. Altered expression levels induced by TGZ may account for the mechanisms underlying the invasion inhibition ability of TZDs and its mode of action.

\section{Acknowledgements}

Not applicable.

\section{Funding}

The present study was supported by the Basic Science Research Program of the National Research Foundation of Korea funded by the Ministry of Education, Republic of Korea (grant no., NRF-2012R1A1A2009579) and the Research Institute for Veterinary Science and the BK21 PLUS Program for Creative Veterinary Science Research, College of Veterinary Medicine, Seoul National University, Korea.

\section{Availability of data and materials}

All data generated or analyzed during this study are included in this published article.

\section{Authors' contributions}

SC performed all experiments, analyzed the data and wrote the manuscript. JL contributed to the cell culture and RT-qPCR. $\mathrm{HO}, \mathrm{UK}$, and BR participated in the MTT assay, wound healing assay and data collection. JP conceived the idea, interpreted the data and helped to draft the manuscript. All authors read and approved the final manuscript.

\section{Ethics approval and consent to participate}

Not applicable.

\section{Patient consent for publication}

Not applicable.

\section{Competing interests}

The authors declare that they have no competing interests.

\section{References}

1. Siegel RL, Miller KD and Jemal A: Cancer statistics, 2015. CA Cancer J Clin 65: 5-29, 2015.

2. Chi KN, Bjartell A, Dearnaley D, Saad F, Schröder FH, Sternberg C, Tombal B and Visakorpi T: Castration-resistant prostate cancer: From new pathophysiology to new treatment targets. Eur Urol 56: 594-605, 2009.

3. Sun Y, Wang BE, Leong KG, Yue P, Li L, Jhunjhunwala S, Chen D, Seo K, Modrusan Z, Gao WQ, et al: Androgen deprivation causes epithelial-mesenchymal transition in the prostate: Implications for androgen-deprivation therapy. Cancer Res 72: 527-536, 2012.

4. Grommes C, Landreth GE and Heneka MT: Antineoplastic effects of peroxisome proliferator-activated receptor gamma agonists. Lancet Oncol 5: 419-429, 2004.

5. Weng JR, Chen CY, Pinzone JJ, Ringel MD and Chen CS: Beyond peroxisome proliferator-activated receptor gamma signaling: The multi-facets of the antitumor effect of thiazolidinediones. Endocr Relat Cancer 13: 401-413, 2006.

6. Wei S, Yang J, Lee SL, Kulp SK and Chen CS: PPARgamma-independent antitumor effects of thiazolidinediones. Cancer Lett 276: 119-124, 2009.

7. Yu HN, Lee YR, Noh EM, Lee KS, Kim JS, Song EK, Han MK, Lee YC, Kwon KB, Lee SJ, et al: Induction of G1 phase arrest and apoptosis in MDA-MB-231 breast cancer cells by troglitazone, a synthetic peroxisome proliferator-activated receptor gamma (PPARgamma) ligand. Cell Biol Int 32: 906-912, 2008.

8. Colin-Cassin C, Yao X, Cerella C, Chbicheb S, Kuntz S, Mazerbourg S, Boisbrun M, Chapleur Y, Diederich M, Flament S and Grillier-Vuissoz I: PPAR $\gamma$-inactive $\Delta 2$-troglitazone independently triggers ER stress and apoptosis in breast cancer cells. Mol Carcinog 54: 393-404, 2015 
9. Ye J, Yin L, Xie P, Wu J, Huang J, Zhou G, Xu H, Lu E and He X: Antiproliferative effects and molecular mechanisms of troglitazone in human cervical cancer in vitro. Onco Targets Ther 8: 1211-1218, 2015.

10. Li MY, Deng H, Zhao JM, Dai D and Tan XY: PPARgamma pathway activation results in apoptosis and COX-2 inhibition in HepG2 cells. World J Gastroenterol 9: 1220-1226, 2003.

11. Chang SN, Han J, Abdelkader TS, Kim TH, Lee JM, Song J, Kim KS, Park JH and Park JH: High animal fat intake enhances prostate cancer progression and reduces glutathione peroxidase 3 expression in early stages of TRAMP mice. Prostate 74 1266-1277, 2014

12. Shiau CW, Yang CC, Kulp SK, Chen KF, Chen CS, Huang JW and Chen CS: Thiazolidenediones mediate apoptosis in prostate cancer cells in part through inhibition of $\mathrm{Bcl}-\mathrm{xL} / \mathrm{Bcl}-2$ functions independently of PPARgamma. Cancer Res 65: 1561-1569, 2005.

13. Santha S, Viswakarma N, Das S, Rana A and Rana B: Tumor necrosis factor-related apoptosis-inducing ligand (TRAIL)-troglitazone-induced apoptosis in prostate cancer cells involve AMP-activated protein kinase. J Biol Chem 290 21865-21875, 2015.

14. Mueller E, Smith M, Sarraf P, Kroll T, Aiyer A, Kaufman DS, Oh W, Demetri G, Figg WD, Zhou XP, et al: Effects of ligand activation of peroxisome proliferator-activated receptor gamma in human prostate cancer. Proc Natl Acad Sci USA 97: 10990-10995, 2000

15. Burstein HJ, Demetri GD, Mueller E, Sarraf P, Spiegelman BM and Winer EP: Use of the peroxisome proliferator-activated receptor (PPAR) gamma ligand troglitazone as treatment for refractory breast cancer: A phase II study. Breast Cancer Res Treat 79: 391-397, 2003

16. Kulke MH, Demetri GD, Sharpless NE, Ryan DP, Shivdasani R, Clark JS, Spiegelman BM, Kim H, Mayer RJ and Fuchs CS: A phase II study of troglitazone, an activator of the PPARgamma receptor, in patients with chemotherapy-resistant metastatic colorectal cancer. Cancer J 8: 395-399, 2002.

17. Thiery JP: Epithelial-mesenchymal transitions in tumour progression. Nat Rev Cancer 2: 442-454, 2002.

18. Christofori G: New signals from the invasive front. Nature 441 444-450, 2006.

19. Yang $J$ and Weinberg RA: Epithelial-mesenchymal transition: At the crossroads of development and tumor metastasis. Dev Cell 14: 818-829, 2008.

20. Frixen UH, Behrens J, Sachs M, Eberle G, Voss B, Warda A, Löchner D and Birchmeier W: E-cadherin-mediated cell-cell adhesion prevents invasiveness of human carcinoma cells. J Cell Biol 113: 173-185, 1991.

21. Livak KJ and Schmittgen TD: Analysis of relative gene expression data using real-time quantitative PCR and the 2(-Delta Delta C(T)) method. Methods 25: 402-408, 2001

22. Day C: Thiazolidinediones: A new class of antidiabetic drugs. Diabet Med 16: 179-192, 1999.

23. Ikezoe T, Miller CW, Kawano S, Kawano S, Heaney A, Williamson EA, Hisatake J, Green E, Hofmann W, Taguchi H and Koeffler HP: Mutational analysis of the peroxisome proliferator-activated receptor gamma gene in human malignancies. Cancer Res 61: 5307-5310, 2001.

24. Matsuyama M and Yoshimura R: Peroxisome proliferator-activated receptor-gamma is a potent target for prevention and treatment in human prostate and testicular cancer. PPAR Res 2008: 249849 , 2008.

25. Sikka S, Chen L, Sethi G and Kumar AP: Targeting PPARgamma signaling cascade for the prevention and treatment of prostate cancer. PPAR Res 2012: 968040, 2012.

26. Yoshizumi T, Ohta T, Ninomiya I, Terada I, Fushida S, Fujimura T, Nishimura G, Shimizu K, Yi S and Miwa K: Thiazolidinedione, a peroxisome proliferator-activated receptor-gamma ligand, inhibits growth and metastasis of HT-29 human colon cancer cells through differentiation-promoting effects. Int J Oncol 25: 631-639, 2004

27. Takano S, Kubota T, Nishibori H, Hasegawa H, Ishii Y, Nitori N, Ochiai H, Okabayashi K, Kitagawa Y, Watanabe M and Kitajima M: Pioglitazone, a ligand for peroxisome proliferator-activated receptor-gamma acts as an inhibitor of colon cancer liver metastasis. Anticancer Res 28: 3593-3599, 2008.

28. Shen B, Chu ES, Zhao G, Man K, Wu CW, Cheng JT, Li G, Nie Y, Lo CM, Teoh N, et al: PPARgamma inhibits hepatocellular carcinoma metastases in vitro and in mice. Br J Cancer 106: 1486-1494, 2012
29. Lee HJ, Su Y, Yin PH, Lee HC and Chi CW: PPAR(gamma)/PGC-1(alpha) pathway in E-cadherin expression and motility of HepG2 cells. Anticancer Res 29: 5057-5063, 2009.

30. Magenta G, Borenstein X, Rolando R and Jasnis MA: Rosiglitazone inhibits metastasis development of a murine mammary tumor cell line LMM3. BMC Cancer 8: 47, 2008.

31. Liu H,Zang C,Fenner MH,Possinger K and Elstner E:PPARgamma ligands and ATRA inhibit the invasion of human breast cancer cells in vitro. Breast Cancer Res Treat 79: 63-74, 2003.

32. Yoo JY, Yang SH, Lee JE, Cho DG, Kim HK, Kim SH, Kim IS, Hong JT, Sung JH, Son BC and Lee SW: E-cadherin as a predictive marker of brain metastasis in non-small-cell lung cancer, and its regulation by pioglitazone in a preclinical model. J Neurooncol 109: 219-227, 2012.

33. Yang DR, Lin SJ, Ding XF, Miyamoto H, Messing E, Li LQ, Wang $\mathrm{N}$ and Chang $\mathrm{C}$ : Higher expression of peroxisome proliferator-activated receptor $\gamma$ or its activation by agonist thiazolidinedione-rosiglitazone promotes bladder cancer cell migration and invasion. Urology 81: 1109.e1-e6, 2013.

34. Qin L, Gong C, Chen AM, Guo FJ, Xu F, Ren Y and Liao H: Peroxisome proliferatoractivated receptor $\gamma$ agonist rosiglitazone inhibits migration and invasion of prostate cancer cells through inhibition of the CXCR4/CXCL12 axis. Mol Med Rep 10: 695-700, 2014

35. Lee JM, Dedhar S, Kalluri R and Thompson EW: The epithelial-mesenchymal transition: New insights in signaling, development, and disease. J Cell Biol 172: 973-981, 2006.

36. Brigelius-Flohé R and Maiorino M: Glutathione peroxidases. Biochim Biophys Acta 1830: 3289-3303, 2013.

37. Zhao H, Li J, Li X, Han C, Zhang Y, Zheng L and Guo M: Silencing GPX 3 expression promotes tumor metastasis in human thyroid cancer. Curr Protein Pept Sci 16: 316-321, 2015.

38. Peng DF, Hu TL, Schneider BG, Chen Z, Xu ZK and El-Rifai W: Silencing of glutathione peroxidase 3 through DNA hypermethylation is associated with lymph node metastasis in gastric carcinomas PLoS One 7: e46214, 2012.

39. Murawaki Y, Tsuchiya H, Kanbe T, Harada K, Yashima K, Nozaka K, Tanida O, Kohno M, Mukoyama T, Nishimuki E, et al: Aberrant expression of selenoproteins in the progression of colorectal cancer. Cancer Lett 259: 218-230, 2008.

40. Agnani D, Camacho-Vanegas O, Camacho C, Lele S, Odunsi K, Cohen S, Dottino P and Martignetti JA: Decreased levels of serum glutathione peroxidase 3 are associated with papillary serous ovarian cancer and disease progression. J Ovarian Res 4: $18,2011$.

41. Brigelius-Flohé R and Kipp A: Glutathione peroxidases in different stages of carcinogenesis. Biochim Biophys Acta 1790: $1555-1568,2009$

42. Chen B, Rao X, House MG, Nephew KP, Cullen KJ and Guo Z: GPx3 promoter hypermethylation is a frequent event in human cancer and is associated with tumorigenesis and chemotherapy response. Cancer Lett 309: 37-45, 2011.

43. He Y, Wang Y, Li P, Zhu S, Wang J and Zhang S: Identification of GPX3 epigenetically silenced by CpG methylation in human esophageal squamous cell carcinoma. Dig Dis Sci 56: 681-688, 2011.

44. Mohamed MM, Sabet S, Peng DF, Nouh MA, El-Shinawi M and El-Rifai W: Promoter hypermethylation and suppression of glutathione peroxidase 3 are associated with inflammatory breast carcinogenesis. Oxid Med Cell Longev 2014: 787195, 2014

45. Lee OJ, Schneider-Stock R, McChesney PA, Kuester D, Roessner A, Vieth M, Moskaluk CA and El-Rifai W: Hypermethylation and loss of expression of glutathione peroxidase-3 in Barrett's tumorigenesis. Neoplasia 7: 854-861, 2005.

46. Lodygin D, Epanchintsev A, Menssen A, Diebold J and Hermeking H: Functional epigenomics identifies genes frequently silenced in prostate cancer. Cancer Res 65: 4218-4227, 2005.

47. Yu YP, Yu G, Tseng G, Cieply K, Nelson J, Defrances M, Zarnegar R, Michalopoulos G and Luo JH: Glutathione peroxidase 3 , deleted or methylated in prostate cancer, suppresses prostate cancer growth and metastasis. Cancer Res 67: 8043-8050, 2007.

48. Sekine Y, Osei-Hwedieh D, Matsuda K, Raghavachari N, Liu D, Furuya Y, Koike H, Suzuki K and Remaley AT: High fat diet reduces the expression of glutathione peroxidase 3 in mouse prostate. Prostate 71: 1499-1509, 2011

49. Wang H, Luo K, Tan LZ, Ren BG, Gu LQ, Michalopoulos G, Luo JH and Yu YP: p53-induced gene 3 mediates cell death induced by glutathione peroxidase 3 . J Biol Chem 287: 16890-16902, 2012.

50. Chang SN, Lee JM, Oh H and Park JH: Glutathione peroxidase 3 inhibits prostate tumorigenesis in TRAMP mice. Prostate 76: $1387-1398,2016$ 